Article

\title{
Characterization of High-Temperature Hierarchical Porous Mullite Washcoat Synthesized Using Aluminum Dross and Coal Fly Ash
}

\author{
Thye Foo Choo ${ }^{1,2}$, Mohamad Amran Mohd Salleh ${ }^{1,3, *}$, Kuan Ying Kok ${ }^{2}$, \\ Khamirul Amin Matori ${ }^{1,4}$ and Suraya Abdul Rashid 1,3 \\ 1 Institute of Advanced Technology, Universiti Putra Malaysia, UPM 43400 Serdang, Selangor, Malaysia; \\ ctfoo@nuclearmalaysia.gov.my (T.F.C.); khamirul@upm.eng.edu.my (K.A.M.); \\ suraya_ar@upm.eng.edu.my (S.A.R.) \\ 2 Malaysian Nuclear Agency (Nuclear Malaysia) Bangi, 43000 Kajang, Selangor, Malaysia; \\ kyk1000@nuclearmalaysia.gov.my \\ 3 Department of Chemical and Environmental Engineering, Universiti Putra Malaysia, \\ UPM 43400 Serdang, Selangor, Malaysia \\ 4 Department of Physics, Faculty of Science, Universiti Putra Malaysia, \\ UPM 43400 Serdang, Selangor, Malaysia \\ * Correspondence: asalleh@upm.edu.my; Tel.: +60-3-8946-6286
}

Received: 16 January 2020; Accepted: 2 February 2020; Published: 6 March 2020

check for updates

\begin{abstract}
Mixture of aluminum dross (AD) and coal fly ash (CFA) was used to produce high-temperature porous mullite for washcoat application. CFA is the combustion by-product of pulverized coal in a coal-fired power plant, while AD is a waste product produced in secondary aluminum refining. In this study, $80 \mathrm{wt} \%$ of $\mathrm{AD}$ and $20 \mathrm{wt} \%$ of CFA was used to prepare a mullite precursor (MP) via acid leaching and dry-milling. The precursor was coated on a substrate and subsequently fired at $1500{ }^{\circ} \mathrm{C}$. The results showed that the precursor transformed to a hierarchical porous microstructure assembled by large interlocked acicular mullite crystals. The pore structures consisted of large interconnected open pores and small pores. The specific surface area of the mullite washcoat was $4.85 \mathrm{~m}^{2} \mathrm{~g}^{-1}$ after heating at $1500{ }^{\circ} \mathrm{C}$ for $4 \mathrm{~h}$. The specific surface area was compatible with the specific surface area of other high-temperature washcoats.
\end{abstract}

Keywords: mullite; washcoat; hierarchical; porous; wastes

\section{Introduction}

High-temperature catalytic processes that aim at creating a more efficient and less polluting chemical process are being used in many applications. For example, emission control of $\mathrm{CO}, \mathrm{NOx}, \mathrm{SOx}$, hydrocarbons, and carbon particles in internal combustion engines, as well as high-temperature fuel cell and catalytic combustion in power stations which utilizes the catalytic process to promote oxidation reactions of fuel and diminish the formation of unwanted products. The catalyst supports used in these processes basically consist of two components. The first component is a honeycomb monolith ceramic that is made of materials with a low coefficient of thermal expansion (CTE) such as cordierite, aluminum titanate, alumina, silicon carbide, and aluminosilicate mixtures. The second component, a small weight fraction of the catalyst support, is a surface covering of washcoat impregnated with the active catalyst (platinum, palladium, or other noble metals).

The washcoat is the crucial component of a catalyst support. It is where the catalytic reactions take place, as the main function of the washcoat is to provide high contact surface area between the catalyst and reacting gases for high reaction rates. Additionally, the washcoat has to be thermally stable at 
working temperatures. A variety of materials that function as a high surface area washcoat such as gamma alumina $\left(\gamma-\mathrm{Al}_{2} \mathrm{O}_{3}\right)$, silica $\left(\mathrm{SiO}_{2}\right)$ and titania $\left(\mathrm{TiO}_{2}\right)$ have been investigated [1-3]. These high surface area materials are intermediate phases that would undergo further phase transformations upon heating at higher temperatures. The phase transformations would normally transform the materials to high temperature stable phases with a lower specific surface area. For example, Gu et al. [4] reported that mesoporous structure of amorphous silicon dioxide with a high surface area of 1200 $\mathrm{m}^{2} \mathrm{~g}^{-1}$ could be maintained up to a temperature of $650{ }^{\circ} \mathrm{C}$, but at the annealing temperature of $800{ }^{\circ} \mathrm{C}$, the mesoporous structure was found to collapse completely. Mahlambi et al. [5] reported that amorphous titania exhibited a large surface area $\left(281.5 \mathrm{~m}^{2} \mathrm{~g}^{-1}\right)$ which decreased to $7.8 \mathrm{~m}^{2} \mathrm{~g}^{-1}$ when the calcination temperature was increased to $600{ }^{\circ} \mathrm{C}$. Similarly, Suoto et al. [6] reported that $\gamma-\mathrm{Al}_{2} \mathrm{O}_{3}$ must be stabilized with alkaline earths or rare earths to slow down the rate at which it was transformed to $\alpha-\mathrm{Al}_{2} \mathrm{O}_{3}$, because this transformation, which occurs at temperatures around $1000{ }^{\circ} \mathrm{C}$, resulted in a substantial loss of surface area of the washcoat. Generally, these washcoat materials cannot maintain their high surface area microstructures under severe conditions at temperatures above $1000{ }^{\circ} \mathrm{C}$.

One material which appears to be a promising candidate for this high-temperature $\left(>1000^{\circ} \mathrm{C}\right)$ washcoat application is mullite, commonly denoted as $3 \mathrm{Al}_{2} \mathrm{O}_{3} \cdot 2 \mathrm{SiO}_{2}$. The advantage of mullite is its ability to produce high thermal stability porous microstructures while exhibiting useful properties such as thermal shock resistance, chemical attack resistance, creep resistance, high heat strength and a low thermal expansion coefficient [7]. Pyzik et al. [8] successfully produced acicular mullite washcoat by a catalytic gas-solid synthesis reaction. The process was based on the formation of fluorotopaz in the presence of silicon tetrafluoride $\left(\mathrm{SiF}_{4}\right)$ gas, and subsequently decomposed to form mullite plus free $\mathrm{SiF}_{4}$ at temperatures above $1000{ }^{\circ} \mathrm{C}$. The catalyzed acicular mullite catalytic filter showed excellent $\mathrm{NO}_{\mathrm{x}}$ reduction. However, the downside of this synthesis process is that it needs to be performed in an enclosed and controlled environment because of the $\mathrm{SiF}_{4}$ gas used, which is very dangerous for human health and the environment.

In this context, the aim of this study is to investigate the feasibility of using aluminum dross (AD) and coal fly ash (CFA) in the production of mullite washcoat via a more environmentally friendly conventional slurry impregnation method. CFA is the combustion by-product of pulverized coal in coal-fired power plant which has a high content of useful silica and alumina, while AD is a high alumina source waste product produced in secondary aluminum refining. The two industrial wastes are suitable as the raw materials for mullite ceramics production. In our previous work, AD and CFA were successfully used to prepare highly crystalline single-phase mullite ceramics [9] and high temperature thermal barrier porous mullite ceramics [10].

\section{Materials and Methods}

The raw material AD was obtained from a local secondary aluminum refining plant in Rawang, Malaysia, and CFA was obtained from Sultan Salahuddin Abdul Aziz coal-fired power plant in Kapar, Malaysia. Mullite precursor powder was produced according to the procedure reported in our previous study [9]. In the process, $80 \mathrm{wt} \%$ of AD was dry-milled with $20 \mathrm{wt} \%$ of CFA using a planetary ball-mill (Fritsch Pulverisette 6) for 1 hour at $300 \mathrm{rpm}$. The mixture was then treated with $2 \mathrm{M}$ hydrochloric acid $(\mathrm{HCl})$ for 1 hour under constant stirring and subsequently filtered off, washed with deionized water, and dried at $100^{\circ} \mathrm{C}$ for $2 \mathrm{~h}$.

The obtained powder mixture was made into slurry using deionized water with $35 \mathrm{wt} \%$ solid content and dip coated on flat alumina substrates. The loaded substrates were withdrawn and the excess mullite precursor slurry was removed by blowing air. The loaded substrates were then dried at $100{ }^{\circ} \mathrm{C}$ for 1 hour and fired at $1200{ }^{\circ} \mathrm{C}$ and $1500{ }^{\circ} \mathrm{C}$ for $4 \mathrm{~h}$ at a rate of $10^{\circ} \mathrm{C} / \mathrm{min}$ in an electrical box furnace. For identification purpose, the unfired loaded-substrate was named as AS, the fired loaded-substrates were named as MA and MB, corresponding to substrates that were fired at $1200^{\circ} \mathrm{C}$ and $1500{ }^{\circ} \mathrm{C}$, respectively. The flow chart of preparing mullite washcoat on alumina substrates is shown in Figure 1. 

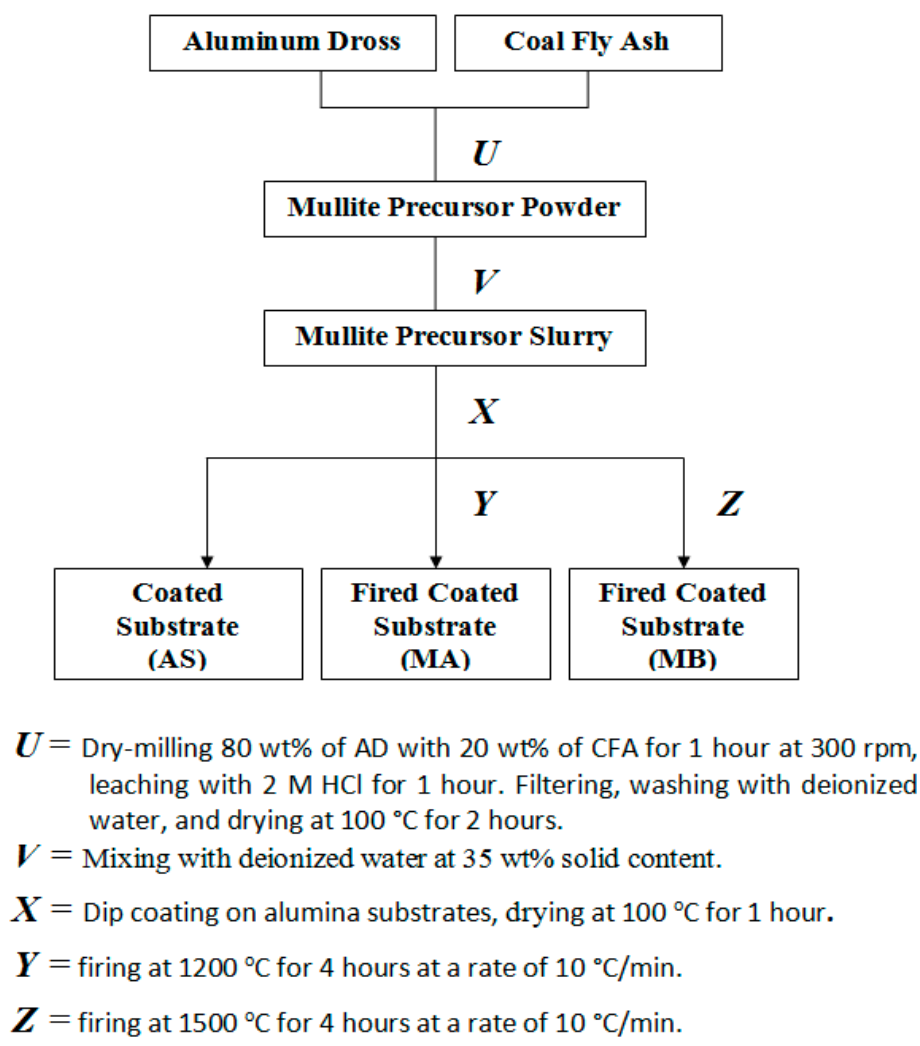

Figure 1. The preparation of mullite washcoat on alumina substrates.

The chemical composition of the starting materials was determined by energy dispersive X-ray fluorescence (EDXRF) using a Shimadzu EDX-7000. Particle size distributions of the powders were measured with the aid of a laser particle size analyzer (Microtrac X100). Zeiss GeminiSEM 500 Field emission scanning electron microscope (FESEM) was used for the study of the morphology of the starting mullite precursor and the sintered mullite washcoat on alumina substrates. The X-ray diffraction (XRD) pattern at room temperature for the samples were recorded by using PANalytical $X^{\prime}$ Pert PRO using monochromated $\mathrm{CuK} \alpha$ radiation $(\lambda=1.54184 \AA)$, and the phase composition was analyzed by Rietveld's refinement method. $\mathrm{N}_{2}$ physical adsorption-desorption isotherm of the washcoat was obtained with a surface area analyzer (Quantachrome Autosorb-1-C) at $77 \mathrm{~K}$. For the Brunauer-Emmer-Teller (BET) surface area measurement, the washcoat was scraped from the substrate, loaded into a sample cell and degassed at $300{ }^{\circ} \mathrm{C}$ for $3 \mathrm{~h}$ prior to the analysis. For the calculation of the BET surface area, relative pressure $\left(\mathrm{P} / \mathrm{P}_{0}\right)$ range of 0.1 to 0.3 was used. The total pore volume was determined from the amount of nitrogen adsorbed at a $\mathrm{P} / \mathrm{P}_{0}$ of 0.995 . The pore size distribution was determined by the Barrett-Joyner-Halenda (BJH) method.

\section{Results and Discussion}

\subsection{Characterization of Starting Materials}

Figure 2 shows the XRD patterns and the identified crystalline phases of the AD and CFA, which were reported in our previous work [9]. The crystalline phases identified in AD were aluminum (ICDD: 98-006-2866), corundum (ICDD: 98-006-3143), iron oxide (ICDD: 98-008-8471), calcium silicate (ICDD: 98-009-9687), hercynite (ICDD: 98-006-3172) and aluminum phosphide (ICDD: 98-007-9264). The major crystalline phases of CFA were quartz (ICDD: 98-004-0867) and mullite (ICDD: 98-008-0384). There is a characteristic broad diffraction peak between $17^{\circ}$ and $30^{\circ}$, centered at 2-theta angle of $22.5^{\circ}$ in the XRD pattern, which attributed to amorphous phase in CFA. 


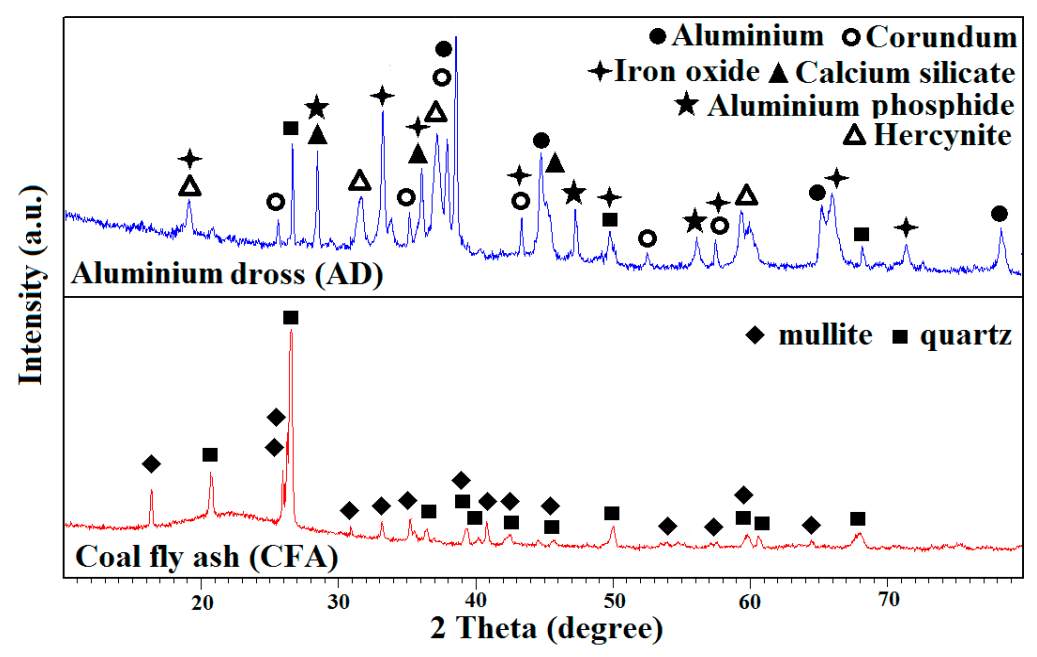

Figure 2. XRD patterns showing the crystalline phase identification of two starting materials: (top) aluminum dross, AD and (bottom) coal fly ash, CFA.

Table 1 provides the chemical composition of AD and CFA determined by EDXRF, which from our previous work [9]. The main chemical components observed in $\mathrm{AD}$ were $\mathrm{Al}_{2} \mathrm{O}_{3}$, while the minor components were $\mathrm{SiO}_{2}, \mathrm{~K}_{2} \mathrm{O}, \mathrm{Fe}_{2} \mathrm{O}_{3}, \mathrm{CaO}, \mathrm{TiO}_{2}, \mathrm{P}_{2} \mathrm{O}_{5}$ and $\mathrm{CuO}$. The chemical components of the CFA were mainly $\mathrm{SiO}_{2}$ and $\mathrm{Al}_{2} \mathrm{O}_{3}$ with a smaller amount of other oxides such as $\mathrm{K}_{2} \mathrm{O}, \mathrm{Fe}_{2} \mathrm{O}_{3}, \mathrm{TiO}_{2}$, $\mathrm{P}_{2} \mathrm{O}_{5}, \mathrm{CaO}$ and $\mathrm{CuO}$. Table 1 also shows the chemical composition of the mullite precursor powder, which was produced using $\mathrm{AD}$ and CFA via the preparation process shown in Figure 1 . The $\mathrm{Al}_{2} \mathrm{O}_{3} / \mathrm{SiO}_{2}$ weight ratio of the mullite precursor powder is 2.48. The value is close to the $\mathrm{Al}_{2} \mathrm{O}_{3} / \mathrm{SiO}_{2}$ weight ratio of a stable stoichiometric $3: 2$ mullite $\left(3 \mathrm{Al}_{2} \mathrm{O}_{3} \cdot 2 \mathrm{SiO}_{2}, 71.8 \mathrm{wt} \% \mathrm{Al}_{2} \mathrm{O}_{3}\right)$ which is calculated as 2.55. The right proportion of $\mathrm{Al}_{2} \mathrm{O}_{3}$ and $\mathrm{SiO}_{2}$ in the precursor is essential to produce a mullite ceramic with good mineralogy and crystallinity. There were small amounts of impurities such as $\mathrm{K}_{2} \mathrm{O}, \mathrm{Fe}_{2} \mathrm{O}_{3}, \mathrm{TiO}_{2}$, $\mathrm{P}_{2} \mathrm{O}_{5}, \mathrm{CaO}$ and $\mathrm{CuO}$ still present in the mullite precursor powder. The presence of these impurities can decrease the viscosity of the mullite precursor powder during sintering and thus promotes mullite phase formation [9].

Table 1. Chemical compositions of aluminum dross (AD) and coal fly ash (CFA).

\begin{tabular}{ccccccccc}
\hline \multirow{2}{*}{ Compound } & \multicolumn{7}{c}{ Content (wt\%) } \\
\cline { 2 - 9 } & $\mathbf{A l}_{\mathbf{2}} \mathbf{O}_{\mathbf{3}}$ & $\mathbf{S i O}_{\mathbf{2}}$ & $\mathbf{K}_{\mathbf{2}} \mathbf{O}$ & $\mathbf{F e}_{\mathbf{2}} \mathbf{O}_{\mathbf{3}}$ & $\mathbf{T i O}_{\mathbf{2}}$ & $\mathbf{P}_{\mathbf{2}} \mathbf{O}_{\mathbf{5}}$ & $\mathbf{C a O}$ & $\mathbf{C u O}$ \\
\hline aluminum dross (AD) & 89.69 & 5.38 & 2.37 & 1.04 & 0.16 & 0.28 & 0.48 & 0.20 \\
coal fly ash (CFA) & 34.48 & 57.13 & 3.67 & 3.46 & 0.48 & 0.33 & 0.32 & $<0.01$ \\
Mullite precursor (MP) & 68.54 & 27.60 & 1.56 & 0.84 & 0.27 & 0.21 & 0.15 & 0.36 \\
\hline
\end{tabular}

Particle size distributions of the starting materials (CFA, AD) and the mullite precursor are shown in Figure 3. The CFA has a very broad size distribution $(2-200 \mu \mathrm{m})$ and a characteristic diameter d50 (average particle size) of $21.83 \mu \mathrm{m}$. The particle size distribution of the AD indicated a narrower size distribution $(0.8-88 \mu \mathrm{m})$ and a smaller $\mathrm{d} 50$ of $11.58 \mu \mathrm{m}$. The results showed that the combined actions of leaching and dry-milling processes effectively produced mullite precursor with a relatively narrower particle size distribution. A smaller d50 of $10.29 \mu \mathrm{m}$ was also recorded for the mullite precursor. Small and homogeneous particles are generally more preferable in washcoat preparation due to their good adherent bond with monolith [11]. 


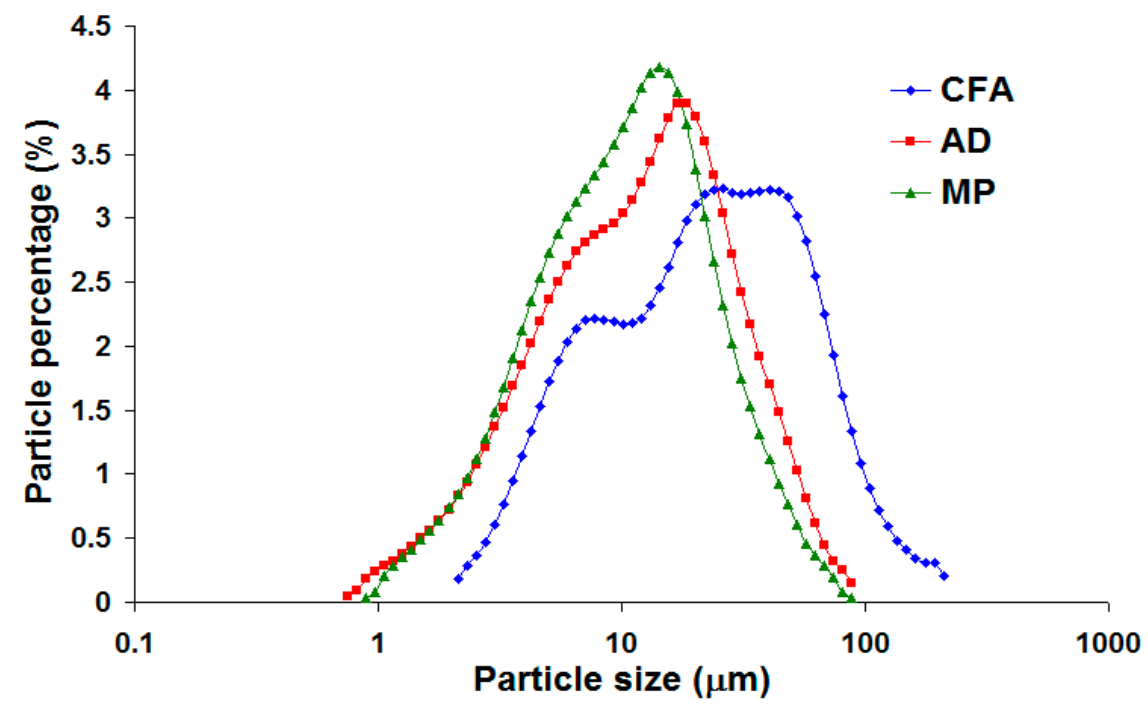

Figure 3. Particle size distributions (logarithmic scale on x-axis) of the CFA, AD and mullite precursor powder.

\subsection{Sintering and Phase Evolution Characterization}

Figure 4 shows the XRD patterns and identified crystalline phases of the mullite precursor powder fired at $1200{ }^{\circ} \mathrm{C}$ and $1500{ }^{\circ} \mathrm{C}$. The single crystalline phase identified in the $1500{ }^{\circ} \mathrm{C}$ fired mullite precursor powder was mullite. The crystalline phases of $1200^{\circ} \mathrm{C}$ fired mullite precursor powder were mullite, corundum, quartz, cristobalite and hercynite. Crystalline phases of the $\mathrm{AD}$ such as aluminum, iron oxide, calcium silicate and aluminum phosphide were not detected in the fired mullite precursor powders. This is most likely due to the leaching by $\mathrm{HCl}$ treatment, heat-induced decomposition, and phase transformation processes.

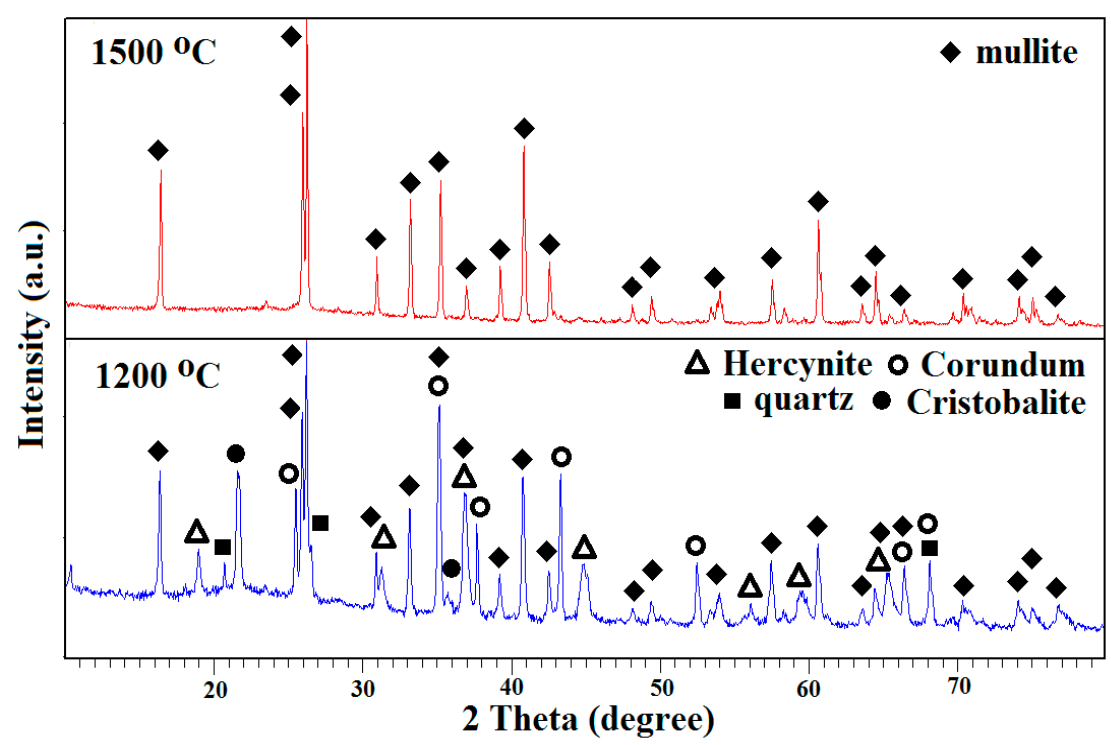

Figure 4. XRD patterns show the crystalline phase identification of two mullite precursor powders fired at (top) $1500{ }^{\circ} \mathrm{C}$ and (bottom) $1200{ }^{\circ} \mathrm{C}$.

The firing temperature plays a significant role in the mullite mineralogy of fired mullite precursor powder. The mineralogical compositions of the mullite precursor powder fired at $120{ }^{\circ} \mathrm{C}$ and $1500{ }^{\circ} \mathrm{C}$ from our previous work [9] are given in Table 2. The result shows that $1500^{\circ} \mathrm{C}$ fired mullite precursor powder is solely comprised of mullite crystalline phase. While the $1200{ }^{\circ} \mathrm{C}$ fired mullite precursor 
powder comprised of several crystalline phases, with mullite $(36.7 \mathrm{wt} \%)$ as the major phase. It still has a large amount of unutilized crystalline $\mathrm{SiO}_{2}(17.4 \mathrm{wt} \%$ quartz, $14.6 \mathrm{wt} \%$ cristobalite) and crystalline $\mathrm{Al}_{2} \mathrm{O}_{3}$ (24.7 $\mathrm{wt} \%$ corundum). The result concludes that a firing temperature of $1200{ }^{\circ} \mathrm{C}$ does not fully combine the crystalline $\mathrm{SiO}_{2}$ and $\mathrm{Al}_{2} \mathrm{O}_{3}$ to form mullite.

Table 2. Mineralogical compositions of the mullite precursor powder fired at $1200{ }^{\circ} \mathrm{C}$ and $1500{ }^{\circ} \mathrm{C}$.

\begin{tabular}{ccccccc}
\hline \multirow{2}{*}{ No. } & \multirow{2}{*}{ Firing Temperature } & \multicolumn{5}{c}{ Composition of Mineralogical Phases (wt.\%) } \\
\cline { 3 - 7 } & & Mullite & Quartz & Cristobalite & Corundum & Hercynite \\
\hline 1 & $1200^{\circ} \mathrm{C}$ & 36.7 & 17.4 & 14.6 & 24.7 & 6.7 \\
2 & $1500^{\circ} \mathrm{C}$ & 100 & 0 & 0 & 0 & 0 \\
\hline
\end{tabular}

Hercynite, which was originated from $\mathrm{AD}$ (Figure 2), was detected in the $1200^{\circ} \mathrm{C}$ fired mullite precursor powder but not in the $1500^{\circ} \mathrm{C}$ fired mullite precursor powder. Hercynite, in its pure form, is a good refractory material with a high melting temperature $\left(1780^{\circ} \mathrm{C}\right)$. The low melting point of hercynite in Table 2 could be attributed to the small amounts of impurities such as $\mathrm{K}_{2} \mathrm{O}, \mathrm{P}_{2} \mathrm{O}_{5}$ and $\mathrm{CaO}$ (Table 1). These impurities have been known for lowering the melting temperature of the ceramic by promoting liquid phase generation during sintering. The low temperature dissolution of hercynite at $1300{ }^{\circ} \mathrm{C}$ was also reported by Liu et al. [12].

Figure 5 consists of FESEM micrographs of the mullite precursor coated on substrate (AS) and the resultant products of firing at $1200{ }^{\circ} \mathrm{C}(\mathrm{MA})$ and $1500{ }^{\circ} \mathrm{C}(\mathrm{MB})$. Figure $5 \mathrm{a}, \mathrm{b}$ show that the initial mullite precursor was consisted of agglomerates with various particle sizes. After firing at $1200^{\circ} \mathrm{C}$, the mullite precursor transformed to a heterogeneous structure (Figure $5 \mathrm{c}$ ) with a fraction of the agglomerated particles melted and fused together. Examination of the melted fraction at a higher magnification showed that the microstructure consisted of a glass matrix with small acicular mullite crystals embedded (Figure 5d). On the other hand, sample MB (Figure 5e), which was fired at a higher temperature of $1500^{\circ} \mathrm{C}$, exhibits a three-dimensional hierarchical porous microstructure assembled by large interlocked acicular mullite crystals (Figure $5 \mathrm{f}$ ). The microstructure of MB has a more evident open porosity compared to MA. The large open pores of MB were well interconnected. Besides the large open pores, small pores were also observed in the microstructure. These small pores were voids between the large interlocked acicular mullite crystals. Generally, the FESEM micrographs showed that although the mullite precursor coated on substrate consisted of agglomerates with various particles sizes (Figure 5a) and has transformed to a heterogeneous structure after being fired at $1200{ }^{\circ} \mathrm{C}$ (Figure $5 \mathrm{c}$ ), the mullite precursor will eventually formed a homogeneous structure after firing at $1500{ }^{\circ} \mathrm{C}$.

Figure 6 shows the schematic diagrams of the mullite washcoat formation mechanism. The formation started in the agglomerated $\mathrm{AD}$ and CFA particles. At a firing temperature of about $1200{ }^{\circ} \mathrm{C}$, the $\mathrm{SiO}_{2}$ in CFA first started to melt and fused with some nearby particles. This is because the $\mathrm{SiO}_{2}$ that originated from CFA was excessive and associated with impurities such as $\mathrm{K}_{2} \mathrm{O}$, $\mathrm{Fe}_{2} \mathrm{O}_{3}, \mathrm{TiO}_{2}, \mathrm{P}_{2} \mathrm{O}_{5}, \mathrm{CaO}$ and $\mathrm{CuO}$. The presence of these impurities has lowered the melting point of the $\mathrm{SiO}_{2}$ and also decreased the viscosity of the molten liquid phase [13]. At the same time, $\mathrm{Al}_{2} \mathrm{O}_{3}$ from the $\mathrm{AD}$ has begun to diffuse into the $\mathrm{SiO}_{2}$-rich molten liquid phase and formed an aluminosilicate molten liquid phase. Meanwhile, the small and relatively stable mullite crystals from CFA still remained inside the aluminosilicate molten liquid phase. As the firing temperature increased above $1200{ }^{\circ} \mathrm{C}$, the small mullite crystals acted as seeds and continued to grow at the expense of the aluminosilicate molten liquid phase. Eventually, at a firing temperature of $1500^{\circ} \mathrm{C}$, the aluminosilicate molten liquid phase has all been used up to form large interlocked acicular mullite crystals. The dimensional shrinkage caused by this removal of the aluminosilicate molten liquid phase subsequently rendered a three-dimensional hierarchical porous microstructure. 


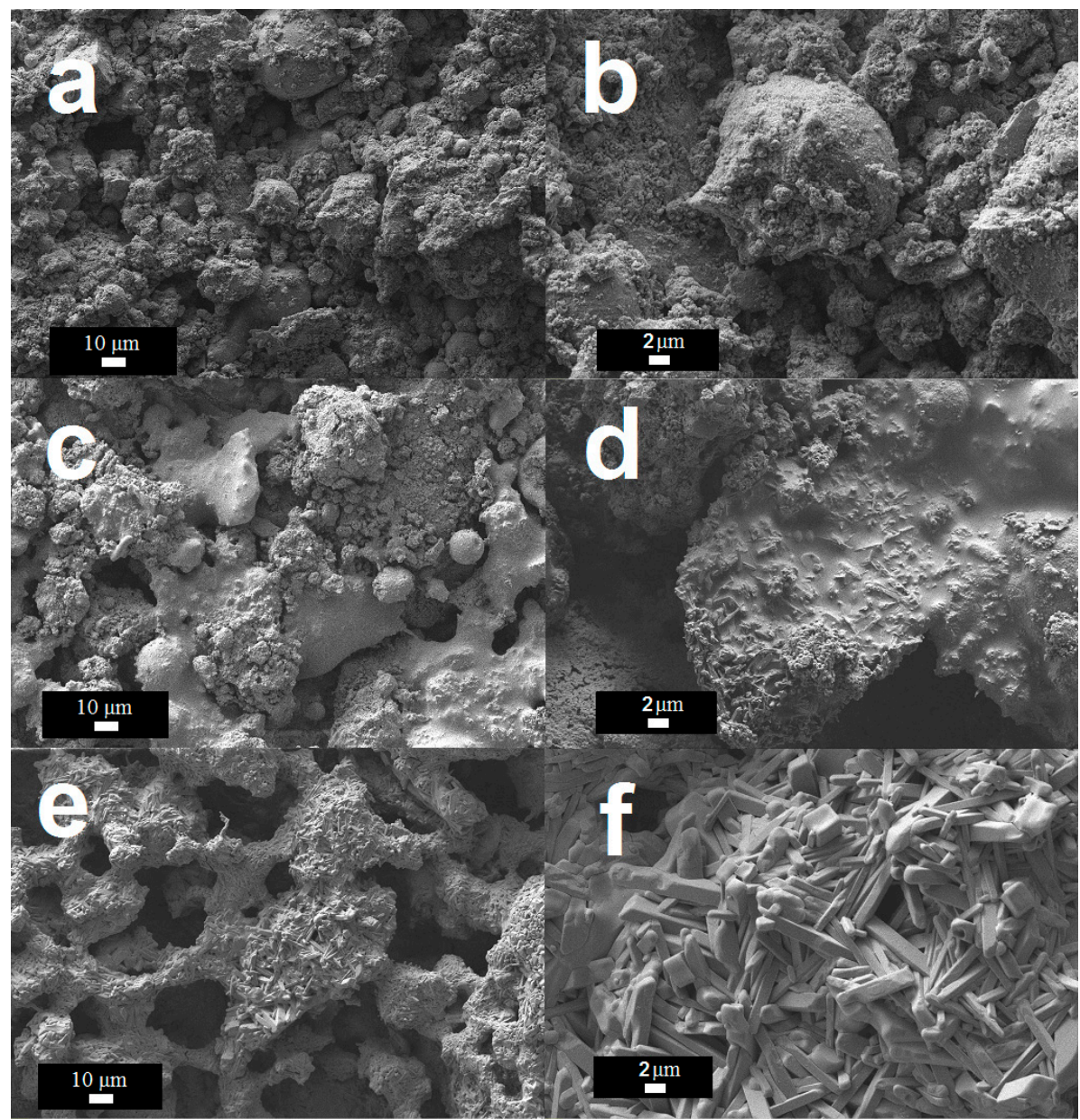

Figure 5. FESEM micrographs of the surface of the mullite precursor coated on substrate, (a) no firing (AS); (c) fired at $1200^{\circ} \mathrm{C}(\mathrm{MA})$; (e) fired at $1500{ }^{\circ} \mathrm{C}(\mathrm{MB})$ and the closer views of (b) AS; (d) MA; (f) MB.

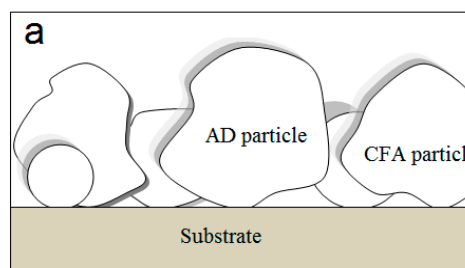

Mullite precursor

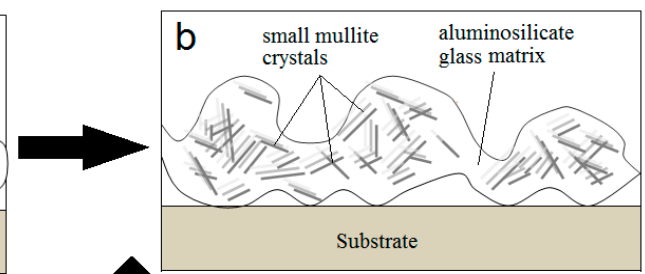

Fired at $1200{ }^{\circ} \mathrm{C}$

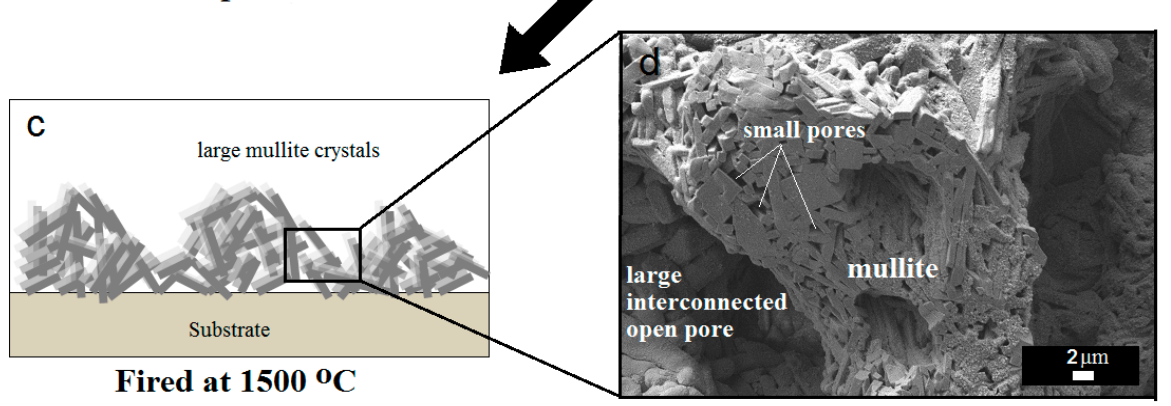

Figure 6. Cross-sectional schematic diagrams showing the mullite washcoat formation mechanism, (a) agglomerated AD and CFA particles as mullite precursor; (b) melting and fusing of particles—small acicular mullite crystals embedded in aluminosilicate glass matrix; (c) dimensional shrinkage and formation of hierarchical porous structure with large interlocked acicular mullite crystals; (d) small pores and large interconnected open pores in the microstructure. 


\subsection{Specific Surface Area and Pore Size Distribution}

Figure 7 showed the nitrogen $\left(\mathrm{N}_{2}\right)$ physical adsorption-desorption isotherms of the washcoat. The obtained adsorption isotherm was used to calculate the specific surface area, total pore volume, average pore size and pore size distribution. The total pore volume and average pore size were $8.79 \times 10^{-3} \mathrm{~cm}^{3} \mathrm{~g}^{-1}$ and $7.25 \mathrm{~nm}$, respectively. The BET specific surface area of the mullite washcoat was $4.85 \mathrm{~m}^{2} \mathrm{~g}^{-1}$. This value is considered very low compared with low-temperature washcoat such as $\gamma$-alumina $\left(200 \mathrm{~m}^{2} \mathrm{~g}^{-1}\right)$ and mesoporous silica $\left(1200 \mathrm{~m}^{2} \mathrm{~g}^{-1}\right)$. However, $\gamma$-alumina and mesoporous silica could not maintain their high surface area at above the temperature of $800^{\circ} \mathrm{C}$ [4] and $1125^{\circ} \mathrm{C}$ [14], respectively. In an application such as catalytic combustion where the temperature range of operation is between 1000 and $1400^{\circ} \mathrm{C}$, a very high surface area washcoat is probably not needed. It was reported that a surface area around $1-10 \mathrm{~m}^{2} \mathrm{~g}^{-1}$ would be sufficient since both mass transfer limitations and reaction rates are high in the application [15].

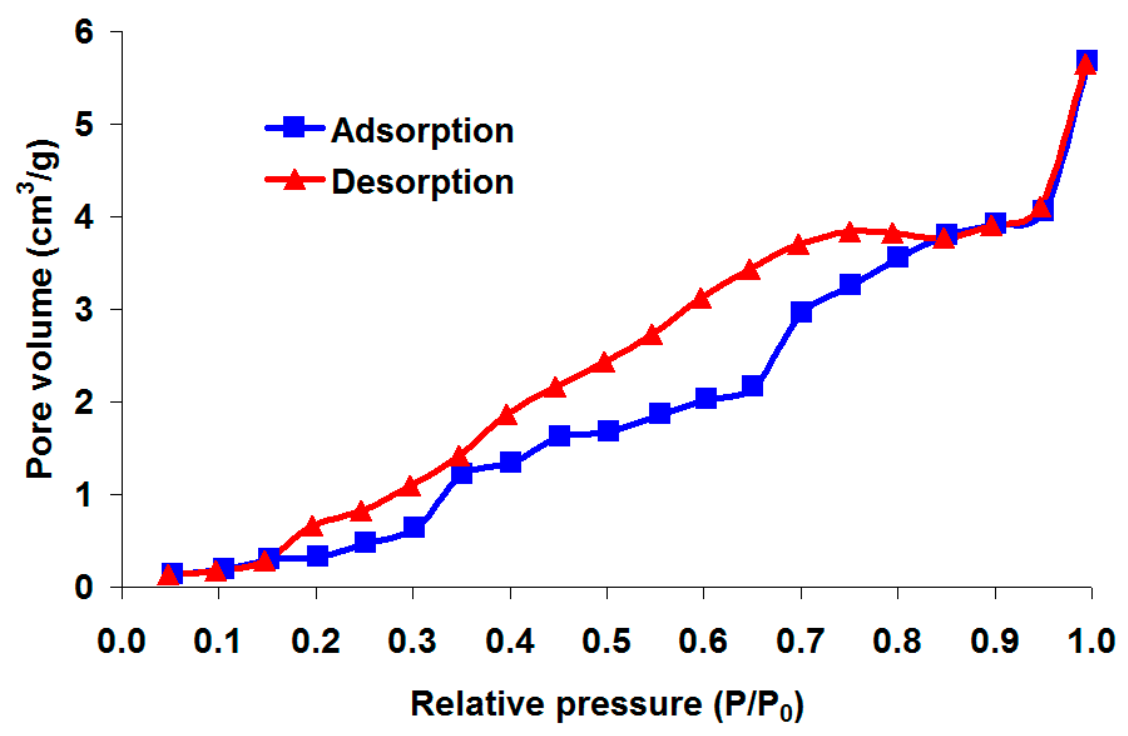

Figure 7. Nitrogen's $\left(\mathrm{N}_{2}\right)$ physical adsorption-desorption isotherms of washcoat synthesized using aluminum dross and coal fly ash.

The BJH method was used to analyze the pore size distribution as shown in Figure 8. The result showed that the pores of the washcoat were consisted of mesopores and macropores. According to the International Union of Pure and Applied Chemistry (IUPAC) classification [16], pores with widths exceeding about $50 \mathrm{~nm}$ are classified as macropores, pores of widths between $2 \mathrm{~nm}$ and $50 \mathrm{~nm}$ are classified as mesopores, and pores with widths not exceeding about $2 \mathrm{~nm}$ are classified as micropores. The adsorption-desorption isotherms (Figure 7) exhibited a hysteresis behavior in the region of relative pressure $\left(\mathrm{P} / \mathrm{P}_{0}\right)$ between 0.15 and 0.85 , this also indicated that the washcoat contained mesopores. A hysteresis appearing in the multilayer range of physisorption isotherms is generally associated with capillary condensation in mesopore structures [16].

A comparison with washcoats from previous studies is shown in Table 3. The comparison showed that the mullite washcoat has a higher specific surface area than the corundum or $\alpha$-alumina washcoat $[6,14]$ at high temperatures. In addition, the mullite also has a low thermal expansion coefficient compared to $\alpha$-alumina from our previous study [9]. This showed that the mullite washcoat was more suitable as a high-temperature washcoat compared to $\alpha$-alumina. 


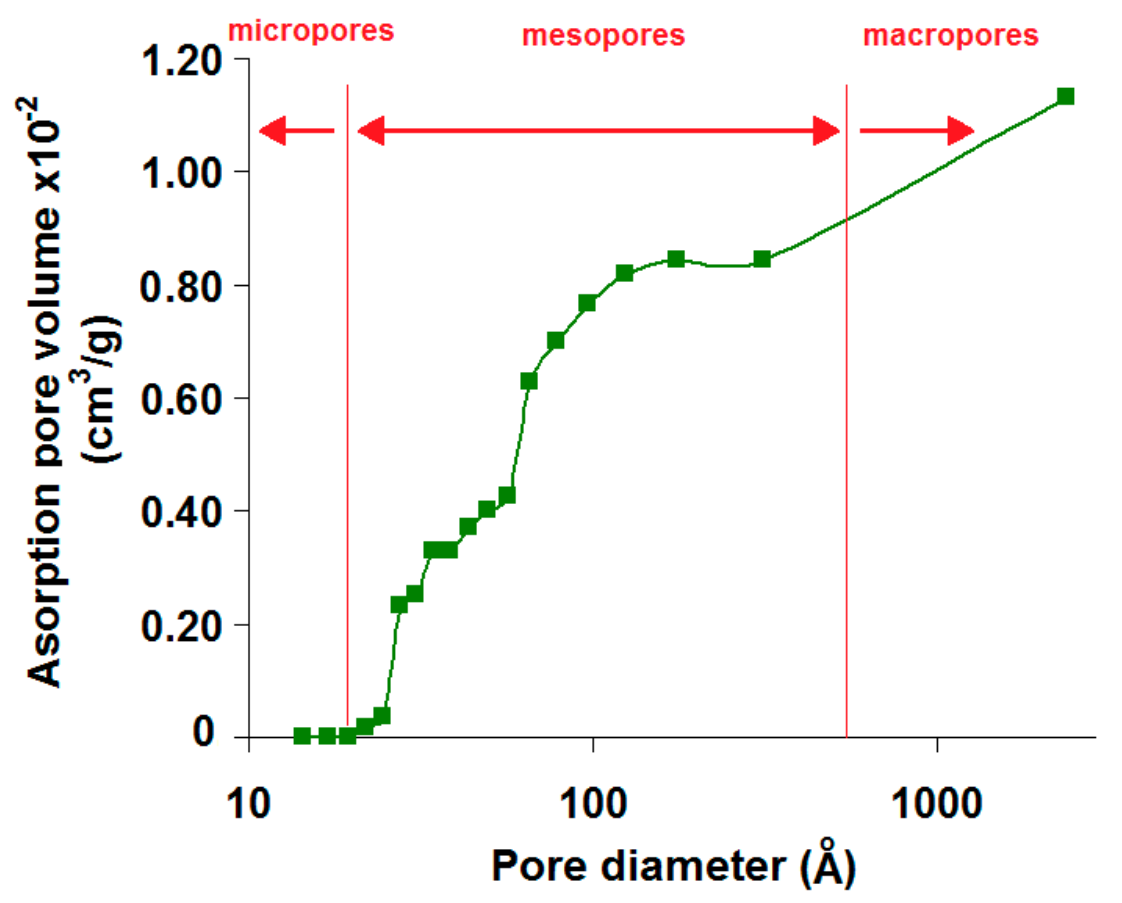

Figure 8. Barrett-Joyner-Halenda (BJH) cumulative pore size distribution (logarithmic scale on the $\mathrm{x}$-axis) of washcoat synthesized using aluminum dross and coal fly ash.

Table 3. Comparison of the Brunauer-Emmer-Teller (BET) specific surface area between the present mullite washcoat and other existing washcoats produced from different raw materials.

\begin{tabular}{|c|c|c|c|c|}
\hline Reference & Raw Materials & Ceramics Product & Synthesis Process & $\begin{array}{l}\text { BET Specific Surface Area } \\
\left(\mathrm{m}^{2} \mathrm{~g}^{-1}\right) / \text { Temperature }\end{array}$ \\
\hline This work & $\begin{array}{c}\text { aluminum dross + } \\
\text { coal fly ash }\end{array}$ & mullite & heating at $1500^{\circ} \mathrm{C}$ & $4.9 / 1500^{\circ} \mathrm{C}$ \\
\hline [6] & kaolin & corundum & $\begin{array}{c}\text { heating at } \\
1300-1500^{\circ} \mathrm{C} \text { in a } \\
\text { controlled reducing } \\
\text { atmosphere }\end{array}$ & $\begin{array}{l}10.5 / 1300^{\circ} \\
\mathrm{C} 8.5 / 1450^{\circ} \\
\mathrm{C} 3 / 1500^{\circ} \mathrm{C}\end{array}$ \\
\hline [14] & boehmite & $\begin{array}{l}\gamma \text {-alumina } \\
\delta \text {-alumina } \\
\theta \text {-alumina } \\
\alpha \text {-alumina }\end{array}$ & $\begin{array}{l}\text { heating at } 450^{\circ} \\
\text { Cheating at } 850^{\circ} \\
\text { Cheating at } 1000^{\circ} \\
\text { Cheating at } 1125^{\circ} \mathrm{C}\end{array}$ & $\begin{array}{l}200 / 450^{\circ} \\
\mathrm{C} 120 / 850^{\circ} \\
\mathrm{C} 50 / 1000^{\circ} \\
\mathrm{C} 1 / 1125^{\circ} \mathrm{C}\end{array}$ \\
\hline [17] & $\begin{array}{c}\text { Aluminum nitrate } \\
\text { nonahydrate }+ \\
\text { Magnesium nitrate } \\
\text { hexahydrate }\end{array}$ & Magnesium aluminate & $\begin{array}{l}\text { Precipitation and } \\
\text { heating at } 1400{ }^{\circ} \mathrm{C}\end{array}$ & $7.5 / 1400^{\circ} \mathrm{C}$ \\
\hline [18] & $\begin{array}{c}\text { Aluminum } \\
\text { isopropoxide }+ \\
\text { lanthanum nitrate }\end{array}$ & $\begin{array}{l}\text { lanthanum } \\
\text { hexaaluminate }\end{array}$ & $\begin{array}{l}\text { Precipitation and } \\
\text { heating at } 1400{ }^{\circ} \mathrm{C}\end{array}$ & $17 / 1400^{\circ} \mathrm{C}$ \\
\hline [19] & $\mathrm{BaCl}_{2}+$ boehmite & Barium hexaaluminate & $\begin{array}{l}\text { Precipitation and } \\
\text { heating at } 1300{ }^{\circ} \mathrm{C}\end{array}$ & $6.6 / 1300^{\circ} \mathrm{C}$ \\
\hline [20] & $\begin{array}{c}\text { Yttrium nitrate }+ \\
\text { Aluminum nitrate }\end{array}$ & $\begin{array}{l}\text { Yttrium aluminum } \\
\text { oxide }\end{array}$ & $\begin{array}{l}\text { Precipitation and } \\
\text { heating at } 1400{ }^{\circ} \mathrm{C}\end{array}$ & $2 / 1400^{\circ} \mathrm{C}$ \\
\hline
\end{tabular}

The specific surface area of the mullite washcoat was also compatible with the specific surface area of other well-studied high-temperature washcoats such as magnesium aluminate, hexaaluminate and yttrium aluminum oxide. Although the specific surface area of the mullite washcoat was slightly lower compared to magnesium aluminate and hexaaluminate, it was within the range of $1-10 \mathrm{~m}^{2} \mathrm{~g}^{-1}$, the minimum requirement suggested by Johansson et al. [15] for catalytic combustion washcoat. It is 
important to note that all these commercial high temperature washcoats [17-20] were synthesized from high purity laboratory chemicals and required precise precipitation and heating processes.

\section{Conclusions}

High-temperature porous mullite washcoat was produced from $\mathrm{AD}$ and CFA industrial wastes. The experimental results revealed that at the firing temperature of $1500^{\circ} \mathrm{C}$, mullite precursor $(80 \mathrm{wt} \%$ $\mathrm{AD}+20 \mathrm{wt} \% \mathrm{CFA}$ ) was fully transformed to a solely mullite crystalline phase. The washcoat consisted of a three-dimensional hierarchical porous microstructure assembled by large interlocked acicular mullite crystals. The pore structures were made up of large interconnected open pores and small pores in the forms of mesopores and macropores. The value of the $\mathrm{N}_{2}$ physisorption BET surface area for the mullite washcoat was $4.85 \mathrm{~m}^{2} \mathrm{~g}^{-1}$. This relatively high surface area after heating at $1500{ }^{\circ} \mathrm{C}$ for $4 \mathrm{~h}$ was compatible with the specific surface area of other high-temperature washcoats such as $\alpha$-alumina, magnesium aluminate, hexaaluminate and yttrium aluminum oxide. Therefore, the mullite washcoat has the potential to be used as washcoat for high temperature applications. In addition, the CFA and $\mathrm{AD}$ are environmentally friendly raw materials, and can be used as an alternative to the expensive industrial chemicals.

Author Contributions: Conceptualization, T.F.C.; compiling and analysis, T.F.C.; writing-original draft preparation, T.F.C., K.Y.K.; writing—review and editing, K.Y.K., M.A.M.S., K.A.M., S.A.R.; supervision, K.Y.K., M.A.M.S., K.A.M., S.A.R. All authors have read and agreed to the published version of the manuscript.

Funding: This research received no external funding.

Conflicts of Interest: The authors declare no conflict of interest.

\section{References}

1. Trueba, M.; Trasatti, S.P. $\gamma$-Alumina as a support for catalysts: A review of fundamental aspects. Eur. J. Inorg. Chem. 2005, 17, 3393-3403. [CrossRef]

2. Huirache-Acuna, R.; Nava, R.; Peza-Ledesma, C.L.; Lara-Romero, J.; Alonso-Nunez, G.; Pawelec, B.; Rivera-Munoz, E.M. SBA-15 mesoporous silica as catalytic support for hydrodesulfurization catalysts-Review. Materials 2013, 6, 4139-4167. [CrossRef] [PubMed]

3. Bagheri, S.; Muhd Julkapli, N.; Bee Abd Hamid, S. Titanium dioxide as a catalyst support in heterogeneous catalysis. Sci. World J. 2014, 2014, 727496. [CrossRef] [PubMed]

4. Gu, G.; Ong, P.P.; Chu, C. Thermal stability of mesoporous silica molecular sieve. J. Phys. Chem. Solids 1999, 60, 943-947. [CrossRef]

5. Mahlambi, M.M.; Mishra, A.K.; Mishra, S.B.; Krause, R.W.; Mamba, B.B.; Raichur, A.M. Comparison of rhodamine B degradation under UV irradiation by two phases of titania nano-photocatalyst. J. Therm. Anal. Calorim. 2012, 110, 847-855. [CrossRef]

6. Souto, A.; Guitian, F. Novel method for obtaining corundum layers of high surface area on ceramic supports for high-temperature catalysis. J. Am. Ceram. Soc. 2002, 85, 1823-1826. [CrossRef]

7. Schneider, H.; Komarneni, S. Basic Properties of Mullite; Mullite Wiley VCH: Weinheim, Germany, 2005; p. 241.

8. Pyzik, A.; Ziebarth, R.; Han, C.; Yang, K. High-porosity acicular mullite ceramics for multifunctional diesel particulate filters. Int. J. Appl. Ceram. Technol. 2011, 8, 1059-1066. [CrossRef]

9. Choo, T.F.; Mohd Salleh, M.A.; Kok, K.Y.; Matori, K.A. Mineralogy and thermal expansion study of mullite-based ceramics synthesized from coal fly ash and aluminum dross industrial wastes. Ceram. Int. 2019, 45, 7488-7494.

10. Choo, T.F.; Mohd Salleh, M.A.; Kok, K.Y.; Matori, K.A. Modified cenospheres as non-sacrificial pore-forming agent for porous mullite ceramics. Ceram. Int. 2019, 45, 21827-21834. [CrossRef]

11. Agrafiotis, C.; Tsetsekou, A. The effect of powder characteristics on washcoat quality. Part I: Alumina washcoats. J. Eur. Ceram. Soc. 2000, 20, 815-824. [CrossRef]

12. Liu, S.; Ma, W.; Zhang, Y.; Zhang, Y.; Qi, K. Sequential Transformation Behavior of Iron-Bearing Minerals during Underground Coal Gasification. Minerals 2018, 8, 90. 
13. Bressiani, J.C.; VIzhevskyi, V.; Bressiani, H.A. Development of the Microstructure of the Silicon Nitride Based Ceramics. Mater. Res. 1999, 2, 165-172. [CrossRef]

14. Argyle, M.D.; Bartholomew, C.H. Heterogeneous Catalyst Deactivation and Regeneration: A Review. Catalysts 2015, 5, 145-269. [CrossRef]

15. Johansson, E.M.; Papadias, D.; Thevenin, P.O.; Ersson, A.G.; Gabrielsson, R.; Menon, P.G.; Björnbom, P.H.; Järäs, S.G. Catalytic combustion for gas turbine applications. Catalysis 1999, 14, 183-235.

16. Sing, K.S.W.; Everett, D.H.; Haul, R.A.W.; Moscou, L.; Pieroti, R.A.; Rouquerol, J.; Siemieniewska, T. Reporting Physisorption Data for Gas/Solid Systems with Special Reference to the Determination of Surface Area and Porosity. Pure Appl. Chem. 1985, 57, 603-619. [CrossRef]

17. Kušar, H.M.J.; Ersson, A.G.; Järäs, S.G. Catalytic combustion of gasified refuse-derived fuel. Appl. Catal. B Environ. 2003, 45, 1-11. [CrossRef]

18. Johansson, E.M.; Danielsson, K.M.J.; Ersson, A.G.; Järäs, S.G. Development of hexaaluminate catalysts for combustion of gasified biomass in gas turbines. J. Eng. Gas Turbines Power 2002, 124, 235-238. [CrossRef]

19. Inoue, H.; Sekizawa, K.; Eguchi, K.; Arai, H. Thermal stability of hexaaluminate film coated on SiC substrate for high-temperature catalytic application. J. Am. Ceram. Soc. 1997, 80, 584-588. [CrossRef]

20. Kušar, H.M.J.; Ersson, A.G.; Thevenin, P.O.; Järäs, S.G. Sulfur poisoning in catalytic combustion of industrial waste. Studies in Surface Science and Catalysis 2001, 139, 463-470.

(C) 2020 by the authors. Licensee MDPI, Basel, Switzerland. This article is an open access article distributed under the terms and conditions of the Creative Commons Attribution (CC BY) license (http://creativecommons.org/licenses/by/4.0/). 